\title{
Intracranial Hypotension Syndrome with Cortical Venous Thrombosis: Letter to the Article Entitled "A Rare Case"
}

\author{
Kortikal Venöz Tromboz ile Beraber Intrakraniyal Hipotansiyon Sendromu:
} Nadir Bir Olgu Adlı Makaleye İlişkin Mektup

Keywords: Intracranial hypotension, cerebral venous thrombosis, magnetic resonance imaging, pathophysiology

Anahtar Kelimeler: İntrakraniyal hipotansiyon, serebral venöz tromboz, manyetik rezonans görüntüleme, patofizyoloji

\section{Dear Editor,}

I read with great interest the report by Jain et al., which smartly illustrated the clinical course of a rare patient diagnosed with intracranial hypotension ( $\mathrm{ICH}$ ) syndrome and concurrent cortical venous thrombosis (CVT) (1). I agree with the interesting aspect of this report and appreciate the authors for presenting such a detailed illustration of this patient. However, I would like comment on this article hoping to provide some new perspectives to the article, as well as the issue of concurrent ICH and CVT.

First, an important point that may be discussed was that the patient had recovered only mildly following conservative treatments with intravenous fluids and steroids. However, anticoagulation treatment had yielded full improvement in the following course. In the literature, there is considerable evidence supporting the occurrence of CVT as a consequence of $\mathrm{ICH}$ $(2,3,4,5)$; hence, treatment of solely $\mathrm{ICH}$, as the inducer agent, was generally recommended (6). In a retrospective review by Schievink and Maya (2), ICH was indicated as a risk factor for CVT; however, there was no evidence for CVT preceeding $\mathrm{ICH}$ in any patient. Thus, this report may give substantial perspectives revealing the role of anticoagulation among the treatment regimens of concurrent ICH and CVT.

However, there may be some limitations while evaluating the presentation of this case. First, the demonstration of recanalization of sinus stenosis in the follow-up using magnetic resonance venography (MRV) might clarify recanalization precisely, and support the rationale of anticoagulation therapy in physiologic aspects. The authors indicated that magnetic resonance imaging (MRI) performed 6 months later revealed a normal study, but an MRV recording was not mentioned in the follow-up. Second, it was not reported as to whether there were any abnormal findings such as empty delta sign (7), which would indicate sinus thrombosis in the first contrast enhancement MRI. Considering that the absence of a flow void and the presence of altered signal intensity in the sinus is a primary finding of sinus thrombosis on conventional MRI (7), conventional MRI findings of the patient have to be enlightened for an accurate diagnosis of the patient. For instance, another crucial diagnosis that might have caused non-visualisation of transverse sinus on MRV is sinus atresia in which conventional MRI does not give any abnormal appearance (7). On the other hand, if the first MRI was negative for CVT, then it can be considered that CVT had developed in the interval period between MRI and MRV recordings. However, a clinical deterioration following the first MRI was not mentioned, in contrary to this hypothesis. Inclusion of these results in the report would also provide information about the evolution time of thrombosis, which may provide substantial insight into the cause-effect relationship of ICH and CVT, as well as their impact seperately on clinical findings.

\footnotetext{
Address for Correspondence/Yazışma Adresi: Halil Önder MD, Yozgat State Hospital, Clinic of Neurology, Yozgat, Turkey

Phone: +90312305 1580 E-mail: halilnder@yahoo.com

Received/Geliş Tarihi: 26.02.2017 Accepted/Kabul Tarihi: 24.03.2017

${ }^{\circ}$ Copyright 2017 by Turkish Neurological Society

Turkish Journal of Neurology published by Galenos Yayınevi.
} 
The occurrence of CVT in patients with $\mathrm{ICH}$ has been reported rarely in the literature with a rate of only $2 \%$ (2). The cause-effect relationship between CVT and ICH has not been clarifed clearly and remains as an interesting issue for further deliberations. Hence the smart illustration of this case constitutes a valuable report for physicians. However, I think that re-evaluation of some points mentioned in this report may add a better understanding and provide subtantial perspectives for physicians. Future reports of larger numbers of patients with concurrent CVT and ICH need to clarify the underlying pathophysiologies of this cooccurrence, as well as the unknown aspects of CSF dynamics.

\section{Ethics}

Peer-review: Internally peer-reviewed.

Financial Disclosure: The authors declared that this study received no financial support.

\section{References}

1. Jain D, Mittal A. Intracranial hypotension syndrome with cortical venous thrombosis: a rare case. Turk J Neurol 2016;22:188-191.

2. Schievink WI, Maya MM. Cerebral venous thrombosis in spontaneous intracranial hypotension. Headache 2008;48:1511-1519.

3. Lan MY, Chang YY, Liu JS. Delayed cerebral venous thrombosis in a patient with spontaneous intracranial hypotension. Cephalalgia 2007;27:11761178.

4. Yoon KW, Cho MK, Kim YJ, Lee SK. Sinus thrombosis in a patient with intracranial hypotension: a suggested hypothesis of venous stasis. a case report. Interv Neuroradiol 2011;17:248-251.

5. Berroir S, Grabli D, Héran F, Bakouche P, Bousser MG. Cerebral sinus venous thrombosis in two patients with spontaneous intracranial hypotension. Cerebrovasc Dis 2004;17:9-12.

6. Menon MK, Prathap M, Jalal MJA. Spontaneous intracranial hypotension complicated with cerebral venous thrombosis and subdural effusion: a case report. Neuroimmunology and Neuroinflammation 2016;3:104-108.

7. Leach JL, Fortuna RB, Jones BV, Gaskill-Shipley MF. Imaging of cerebral venous thrombosis: current techniques, spectrum of findings, and diagnostic pitfalls. Radiographics 2006;26(Suppl 1):19-41. 